\title{
Water Relations and Gas Exchanges of West Indian Cherry under Salt Stress and Nitrogen and Phosphorus Doses
}

\author{
Francisco V. da S. Sá ${ }^{1}$, Hans R. Gheyi ${ }^{1}$, Geovani S. de Lima ${ }^{1}$, Emanoela P. de Paiva ${ }^{2}$, Pedro D. Fernandes ${ }^{1}$, \\ Romulo C. L. Moreira ${ }^{1}$, Luderlandio de A. Silva ${ }^{1} \&$ Miguel Ferreira Neto ${ }^{3}$ \\ ${ }^{1}$ Academic Unit of Agricultural Engineering, Federal University of Campina Grande, Campina Grande, Brazil \\ ${ }^{2}$ Department of Plant Production, Federal Rural University of Semi-Arid, Mossoró, Brazil \\ ${ }^{3}$ Department of Environmental and Technological Sciences, Federal Rural University of Semi-Arid, Mossoró, \\ Brazil \\ Correspondence: Francisco V. da S. Sá, Academic Unit of Agricultural Engineering, Federal University of \\ Campina Grande, Paraíba, Brazil. Tel: 55-083-99861-9267. E-mail: vanies_agronomia@hotmail.com
}

Received: July 11, 2017

doi:10.5539/jas.v9n10p168
Accepted: August 17, $2017 \quad$ Online Published: September 15, 2017

URL: https://doi.org/10.5539/jas.v9n10p168

\begin{abstract}
This study aimed to evaluate the interaction between the fertilization with nitrogen $(\mathrm{N})$ and phosphorus $(\mathrm{P})$ and irrigation with saline water on the water relations, gas exchanges and chlorophyll $a$ fluorescence in West Indian cherry in the vegetative stage. The study was carried out in protected environment, using lysimeters filled with clay loam Regolithic Neosol, with low P content, installed in a randomized block design, arranged in a factorial scheme with five levels of electrical conductivity of irrigation water (ECw), and four managements of $\mathrm{P}$ and $\mathrm{N}$ fertilization, with three replicates and one plant per plot. Along the experiment, water relations, gas exchanges and chlorophyll $a$ fluorescence were evaluated in West Indian cherry plants. The increase in irrigation water salinity reduces the gas exchanges of the plants, but the increment of $40 \%$ in $\mathrm{N}$ supply increases the photosynthetic activity of West Indian cherry at recommendation levels higher than $100: 100 \%$ of the $\mathrm{P} / \mathrm{N}$ ratio, when irrigated with $\mathrm{ECw}$ of up to $3.0 \mathrm{dS} \mathrm{m}^{-1}$. The combined action of $\mathrm{N}$ and $\mathrm{P}$, at doses of $140: 140 \% \mathrm{~N} / \mathrm{P}$ recommendation, increases leaf turgor in the plants, regardless of the $\mathrm{ECw}$ level. The increment of $40 \%$ in $\mathrm{N}$ dose reduces the effects of salinity on the initial fluorescence of chlorophyll $a$ in West Indian cherry irrigated with up to $2.2 \mathrm{dS} \mathrm{m}^{-1}$.
\end{abstract}

Keywords: Malphigia emarginata, photosynthesis, fluorescence, soil fertility

\section{Introduction}

West Indian cherry (Malpighia emarginata DC) has an attractive fruit for its pleasant taste and high contents of vitamin C, vitamin A, iron, calcium and vitamins B-complex (Thiamin, Riboflavin, and Niacin) (Adriano et al., 2011). In Brazil, the crop is widely cultivated, especially in semi-arid areas of the states of Bahia, Ceará, Paraíba and Pernambuco, the main producers of the country (Adriano et al., 2011; Esashika et al., 2013). Despite the great adaptability to semi-arid conditions, the reduction in the water volume of the water sources of the region, combined with the high concentration of salts found in the water, it is necessary to look for management strategies that enable the use of low-quality (saline) waters in the irrigation of the crops (Medeiros et al., 2003).

In general, the effects of water and/or soil salinity on plants are attributed to the reduction in the osmotic potential, specific ion concentration and to the nutritional and hormonal imbalance (Esteves \& Suzuki, 2008; Munns \& Tester, 2008; Sá et al., 2015). In cultivated plants, innumerous effects are caused by the excess of salts in the soil, including disorders in the permeability of cell membranes, alterations in stomatal conductance, photosynthesis and ionic balance, which lead to reduction in plant growth and development, regardless of the nature of the salts (Silva et al., 2014; Lima et al., 2015). Thus, it becomes necessary to identify the most adequate strategy for the management of water and/or soil salinity, aiming to maintain the physiological status of the plants cultivated under salt stress conditions.

Among the salinity management strategies in agriculture, fertilization with nitrogen $(\mathrm{N})$ and phosphorus $(\mathrm{P})$, evaluated separately, have shown promising results in the mitigation of the deleterious effects caused by water and/or soil salinity on crop production (Santos et al., 2010), especially the mitigating action of $\mathrm{N}$ on salt stress in 
cultivated plants (Furtado et al., 2014; Guedes Filho et al., 2015), due to its functionality in the osmotic adjustment (constituent of various protective osmolytes) and in the protection of macromolecules (Esteves \& Suzuki, 2008). Although less expressive, compared with N, some studies have obtained promising results in the evaluations involving the interaction $\mathrm{P}$ vs. salinity, since this nutrient is directly related to the energetic processes of the cells (Lacerda et al., 2006; Oliveira et al., 2010; Taiz et al., 2015).

In the literature, there are no studies involving the combined action of $\mathrm{N}$ and $\mathrm{P}$ aiming to mitigate the deleterious effects of salt stress on West Indian cherry. Hence, the present study aimed to evaluate the interaction of $\mathrm{N}$ and $\mathrm{P}$ fertilization and saline water irrigation on the water relations, gas exchanges and chlorophyll $a$ fluorescence of West Indian cherry in the vegetative stage.

\section{Material and Methods}

The experiment was carried out from June to September 2016 in a protected environment (greenhouse) of the Center of Technology and Natural Resources (CTRN) of the Federal University of Campina Grande (UFCG), located in the municipality of Campina Grande-PB, Brazil, at the geographic coordinates of $7^{\circ} 15^{\prime} 18^{\prime \prime} \mathrm{S}$, $35^{\circ} 52^{\prime} 28^{\prime \prime} \mathrm{W}$ and mean altitude of $550 \mathrm{~m}$.

The experiment was installed in a randomized block design, in a factorial scheme, with five levels of irrigation water electrical conductivity-ECw $\left(0.6 ; 1.4 ; 2.2 ; 3.0\right.$ and $\left.3.8 \mathrm{dS} \mathrm{m}^{-1}\right)$ and four proportions of $\mathrm{P}$ and $\mathrm{N}$ fertilization $(100: 100 ; 140: 100 ; 100: 140$ and 140:140\% of recommended dose), with three replicates and one plant per plot. The application of $100 \% \mathrm{~N}$ fertilization $\left(23.85 \mathrm{~g}\right.$ of $\mathrm{N}$ plant year $\left.^{-1}\right)$ and $100 \% \mathrm{P}$ fertilization $\left(45.0 \mathrm{~g}\right.$ of $\mathrm{P}_{2} \mathrm{O}_{5}$ plant $^{-1}$ year $^{-1}$ ) was based on the recommendations of Musser (1955).

West Indian cherry plants were cultivated in lysimeters with capacity for $250 \mathrm{dm}^{3}$, filled with $235 \mathrm{~kg}$ of soil placed above a geotextile (Bidim) and a $0.5-\mathrm{kg}$ layer of crushed stone. The soil material used to fill the lysimeters was classified as Regolithic Neosol with clay loam texture $(0-30 \mathrm{~cm}$ layer), from the municipality of Esperança-PB. After the material was pounded to break up clods, a composite sample was collected for the characterization of its physical and chemical attributes (Table 1), based on methodologies proposed by Claessen (1997).

Table 1. Chemical and physico-hydraulic characteristics of the soil used in the experiment

\begin{tabular}{|c|c|c|c|c|c|c|c|c|c|}
\hline \multicolumn{10}{|c|}{ Chemical characteristics } \\
\hline $\mathrm{pH}_{\left(\mathrm{H}_{2} \mathrm{O}\right)}(1: 2.5)$ & O.M. & $\mathrm{P}$ & $\mathrm{K}^{+}$ & $\mathrm{Na}^{+}$ & $\mathrm{Ca}^{2+}$ & $\mathrm{Mg}^{2+}$ & $\mathrm{Al}^{3+}$ & $\mathrm{H}^{+}$ & ECse \\
\hline & --- dag kg ${ }^{-1}---$ & --- $\mathrm{mg} \mathrm{kg}^{-1}---$ & \multicolumn{6}{|c|}{ 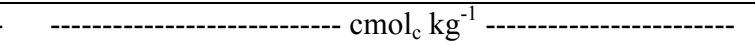 } & \multirow{2}{*}{$\begin{array}{l}---\mathrm{dS} \mathrm{m}{ }^{-1}--- \\
0.61\end{array}$} \\
\hline 5.63 & 1.830 & 18.20 & 0.21 & 0.17 & 3.49 & 2.99 & 0.00 & 5.81 & \\
\hline \multicolumn{10}{|c|}{ Physical characteristics } \\
\hline \multicolumn{2}{|c|}{ Granulometric fraction } & Tortu & \multicolumn{3}{|c|}{ Moisture content } & & \multirow{2}{*}{ Total porosity } & \multirow{2}{*}{$\mathrm{D}_{\mathrm{A}}$} & \multirow{2}{*}{$\mathrm{D}_{\mathrm{P}}$} \\
\hline Silte & Clay & ural & $33.42 \mathrm{kPa}$ & 1519 & $\mathrm{kPa}$ & & & & \\
\hline \multicolumn{2}{|c|}{------------- $\mathrm{g} \mathrm{kg}^{-1}$----------- } & & \multicolumn{3}{|c|}{------- dag kg ${ }^{-1}$-------- } & & \multirow{2}{*}{$\begin{array}{l}----\mathrm{m}^{3} \mathrm{~m}^{-3} \text {---- } \\
0.5735\end{array}$} & \multicolumn{2}{|c|}{---- $\mathrm{kg} \mathrm{dm}^{-3}$---- } \\
\hline 572.7 & 326.6 & CL & 12.68 & 4.98 & & 7.70 & & 1.13 & $3 \quad 2.65$ \\
\hline
\end{tabular}

Note. O.M.: Organic matter: Walkley-Black wet digestion; $\mathrm{Ca}^{2+}$ and $\mathrm{Mg}^{2+}$ extracted with $1 \mathrm{~mol} \mathrm{~L}^{-1} \mathrm{KCl}$ at $\mathrm{pH} 7.0$; $\mathrm{Na}^{+}$and $\mathrm{K}^{+}$extracted using 1 mol L-1 $\mathrm{NH}_{4} \mathrm{OAc}$ at $\mathrm{pH}$ 7.0; ECse: electrical conductivity of the soil saturation extract; CL: Clay loam; AW: Available water; $\mathrm{D}_{\mathrm{A}}$ : Apparent density; $\mathrm{D}_{\mathrm{P}}$ : Particle density.

The experiment used plantlets of the West Indian cherry cultivar BRS 366-Jaburu, grafted on 'Criolo' rootstock, from the Germoplasm collection of EMBRAPA Tropical Agroindustry, in Pacajus-CE. The obtained plantlets were 240 days old and, during this time, were irrigated only with low-salinity water $\left(0.6 \mathrm{dS} \mathrm{m}^{-1}\right)$. Subsequently, they were transplanted to the lysimeters 90 days after grafting. After transplanting, the plantlets were acclimated for a period of 30 days before the beginning of the application of salinity treatments.

Waters with lowest $\mathrm{ECw}\left(0.6\right.$ and $\left.1.4 \mathrm{dS} \mathrm{m}^{-1}\right)$ were obtained by the dilution of municipal-supply water $(\mathrm{ECw}=$ $\left.1.78 \mathrm{dS} \mathrm{m}^{-1}\right)$ using rainwater $\left(0.04 \mathrm{dS} \mathrm{m}^{-1}\right)$, while the other $\mathrm{ECw}\left(2.2,3.0\right.$ and $\left.3.8 \mathrm{dS} \mathrm{m}^{-1}\right)$ were prepared through the addition of salts $\left(\mathrm{NaCl}, \mathrm{CaCl}_{2} \cdot 2 \mathrm{H}_{2} \mathrm{O}\right.$ and $\left.\mathrm{MgSO}_{4} \cdot 6 \mathrm{H}_{2} \mathrm{O}\right)$ in the public-supply water, in equivalent proportion of 7:2:1 among the ions $\mathrm{Na}, \mathrm{Ca}$ and $\mathrm{Mg}$, respectively. This ratio represents the mean composition of the contents of ions present in the waters used for irrigation in the semi-arid region of Northeast Brazil (Medeiros et al., 2003). 
The irrigation with the distinct ECw levels was performed at 3-day intervals, applying the water volume in each lysimeter to maintain the moisture content close to the ideal water holding capacity of the soil $(33.42 \mathrm{kPa})$. In each irrigation the water volume necessary to meet the water requirements of the plants, estimated through the water balance in the root zone was applied. To avoid the accumulation of salts in the root zone, a leaching fraction of 0.10 was used every 30 days (Ayers \& Westcot, 1985).

$\mathrm{N}$ and $\mathrm{P}$ fertilizations were performed according to the pre-established treatments, using as sources urea $(45 \% \mathrm{~N})$ and single superphosphate $\left(18 \% \mathrm{P}_{2} \mathrm{O}_{5}, 18 \% \mathrm{Ca}, 12 \% \mathrm{~S}\right)$, respectively. To meet $\mathrm{K}$ requirement, $19.8 \mathrm{~g}$ of $\mathrm{K}_{2} \mathrm{O}$ were applied per plant, in the form of potassium chloride $\left(60 \% \mathrm{~K}_{2} \mathrm{O}\right)$ split into 12 monthly applications of $2.75 \mathrm{gl}$ per plant. Phosphorus (250 or $350 \mathrm{~g}$ of superphosphate, according to the treatment) was applied as basal fertilization. Nitrogen fertilization was split into 24 equal installments, at 15-day intervals along the year, to apply $2.21 \mathrm{~g}$ in the treatment of $100 \%$ and $3.09 \mathrm{~g}$ of urea per plant in the treatment of $140 \% \mathrm{~N}$. Fertilizations with $\mathrm{N}$ and $\mathrm{K}$ started 15 days after transplanting the seedlings to the lysimeters.

The cultivation and phytosanitary practices recommended for the crop were performed along the experiment, by monitoring the occurrence of pests and diseases and adopting control measures when necessary.

Gas exchanges in West Indian cherry were determined at 45 days after applying the salinity levels, using a portable photosynthesis meter ("LCPro+"-ADC Bio Scientific Ltd.), operating with control of temperature at 25 ${ }^{\circ} \mathrm{C}$, irradiation of $1200 \mu \mathrm{mol}$ photons $\mathrm{m}^{-2} \mathrm{~s}^{-1}$ and air flow of $200 \mathrm{~mL} \mathrm{~min}^{-1}$, and at atmospheric level of $\mathrm{CO}_{2}$, to obtain the following variables: $\mathrm{CO}_{2}$ assimilation rate- $A\left(\mu \mathrm{mol} \mathrm{m} \mathrm{m}^{-2} \mathrm{~s}^{-1}\right.$ ), transpiration- $E$ (mol of $\mathrm{H}_{2} \mathrm{O} \mathrm{m}^{-2} \mathrm{~s}^{-1}$ ), stomatal conductance-gs (mol of $\mathrm{H}_{2} \mathrm{O} \mathrm{m}^{-2} \mathrm{~s}^{-1}$ ) and internal $\mathrm{CO}_{2}$ concentration $(\mathrm{C} i)$ in the third leaf from the apex. These data were used to quantify the instantaneous water use efficiency (WUEi) (A/T) $\left[\left(\mu \mathrm{mol} \mathrm{m}^{-2} \mathrm{~s}^{-1}\right)\left(\mathrm{mol} \mathrm{H}_{2} \mathrm{O}\right.\right.$ $\left.\left.\mathrm{m}^{-2} \mathrm{~s}^{-1}\right)^{-1}\right]$ and instantaneous carboxylation efficiency-A/Ci (EiCi) (Silva et al., 2014).

In the same period, chlorophyll $a$ fluorescence was determined using a pulse-modulated fluorometer (Model OS5p-Opti Science). Firstly, the $\mathrm{Fv} / \mathrm{Fm}$ protocol was used, in order to determine the variables: Initial fluorescence (Fo), Maximum Fluorescence ( $\mathrm{Fm})$, Variable fluorescence $(\mathrm{Fv}=\mathrm{Fm}-\mathrm{Fo})$ and maximum quantum efficiency of photosystem II (Fv/Fm) (Maxwell \& Johnson, 2000). This protocol was performed after adaptation of the leaves to the dark for a period of $30 \mathrm{~min}$, using a clip of the device, to guarantee that all acceptors were oxidized, i.e., with open reaction centers.

In the evaluation of the West Indian cherry water status, three fully expanded leaves were collected from the mid third portion of each plant to determine the relative water content in the leaf blade and leaf water saturation deficit. For that, fresh weight (FW) was determined immediately after leaf collection; then, the leaf samples were placed in plastic bags, immersed in distilled water and stored for 24 hours. After this period, the excess of water was removed with paper towel, to obtain the turgid weight (TW). Then, the samples were taken to the oven (temperature $\approx 65{ }^{\circ} \mathrm{C} \pm 3{ }^{\circ} \mathrm{C}$, until constant weight), to obtain the dry weight (DW). The relative water content (RWC) was determined through the methodology described in Taiz et al. (2015), using Equation (1):

$$
\mathrm{RWC}=\frac{\mathrm{FW}-\mathrm{DW}}{\mathrm{TW}-\mathrm{DW}} \times 100
$$

Where,

RWC = relative water content (\%); FW = leaf fresh weight (g); TW = turgid weight (g); DW = dry weight (g).

The water saturation deficit (WSD) was determined according to the methodology described by Lima et al. (2015), using Equation (2):

$$
\mathrm{WSD}=100-\mathrm{RWC}
$$

The data were subjected to analysis of variance (F test). In case of significance of the isolated factors, the salinity levels were evaluated through polynomial regression analysis $(\mathrm{p}<0.05)$ and the means of $\mathrm{N}$ and $\mathrm{P}$ doses were compared by Tukey test, also at 0.05 probability level. In cases of significant interaction, a follow-up analysis was applied to the $\mathrm{N}$ and $\mathrm{P}$ doses for each salinity level, through regression analysis $(0.05$ or 0.01 probability level), using the program Sisvar version 5.1 (Ferreira et al., 2011).

\section{Results and Discussion}

There was significant interaction $(\mathrm{p}<0.05)$ of the water salinity levels and fertilization managements on the plants, for the variables $\mathrm{CO}_{2}$ assimilation rate $(A)$, internal $\mathrm{CO}_{2}$ concentration $(\mathrm{Ci})$, instantaneous carboxylation efficiency $(E i C i)$, transpiration $(E)$, instantaneous water use efficiency (WUEi) and initial fluorescence $(F o)$ (Table 2$)$. Stomatal conductance $(g s)$ was significantly $(\mathrm{p}<0.05)$ affected only by the irrigation water salinity levels, while the fertilization managements influenced $(\mathrm{p}<0.05)$ the variables relative water content $(\mathrm{RWC})$ and 
water saturation deficit (WSD) (Table 2). Except for initial fluorescence (Fo), as already mentioned, there were no significant $(\mathrm{p}>0.05)$ effects of the tested treatments on the other variables of fluorescence, maximum $(\mathrm{Fm})$, variable $(F v)$ and quantum efficiency of photosystem II $(F v / F m)$ (Table 2$)$.

The highest relative water content $(\mathrm{RWC}=80.65 \%)$ was observed in plants fertilized with $140: 140 \% \mathrm{P} / \mathrm{N}$, exceeding by $11.35 \%$ the value found in plants cultivated with $100: 100 \% \mathrm{P} / \mathrm{N}$ (control). Consequently, the water saturation deficit $(\mathrm{WSD}=19.35 \%)$ was inferior in plants subjected to that treatment $(140: 140 \% \mathrm{P} / \mathrm{N}), 29.81 \%$ lower in comparison to those under the control treatment (Figures 1A and 1B). Therefore, the increment of $40 \%$ in $\mathrm{N}$ and $\mathrm{P}$ led to higher water content in the leaves (RWC) and, consequently, lower WSD, regardless of the water salinity levels, compared with the other treatments. Plants in this treatment $(140: 140 \% \mathrm{P} / \mathrm{N})$ managed to maintain a higher turgor potential in the leaf cells, probably due to the higher capacity of osmotic adjustment promoted by the synthesis of compatible osmolytes, such as amino acids and soluble sugars, stimulated by the increment of $\mathrm{N}$ and $\mathrm{P}$, thus reducing the imbalance between transpiration and water absorption by plants (Santana et al., 2011), favoring the ionic homeostasis (Gupta \& Huag, 2014).

Table 2. Summary of the F test significance for relative water content (RWC), water saturation deficit (WSD), $\mathrm{CO}_{2}$ assimilation rate $(A)$, internal $\mathrm{CO}_{2}$ concentration $(\mathrm{Ci})$, instantaneous carboxylation efficiency (EiCi), stomatal conductance $(g s)$, transpiration $(E)$, instantaneous water use efficiency (WUEi), initial fluorescence $(F o$ ), maximum fluorescence $(F m)$, variable fluorescence $(F v)$ and quantum efficiency of photosystem II $(F v / F m)$ of West Indian cherry irrigated with saline waters and fertilized with nitrogen and phosphorus at 45 days after application of the saline levels

\begin{tabular}{llllllll}
\hline \multirow{2}{*}{ SV } & DF & \multicolumn{7}{c}{ Test 'F' significance } \\
\cline { 2 - 7 } & & RWC & WSD & A & Ci & EiCi & gs \\
\hline Block & 2 & $\mathrm{~ns}$ & $\mathrm{~ns}$ & $\mathrm{~ns}$ & $\mathrm{~ns}$ & $\mathrm{~ns}$ & $*$ \\
Sal & 4 & $\mathrm{~ns}$ & $\mathrm{~ns}$ & $*$ & $\mathrm{~ns}$ & $*$ & $*$ \\
Fertilizer & 3 & $*$ & $*$ & $\mathrm{~ns}$ & $*$ & $\mathrm{~ns}$ & $\mathrm{~ns}$ \\
Sal x Fertilizer & 12 & $\mathrm{~ns}$ & $\mathrm{~ns}$ & $*$ & $*$ & $*$ & $\mathrm{~ns}$ \\
\hline CV & & 7,45 & 22,86 & 19,32 & 16,35 & 25,36 & 28,09 \\
\hline SV & FD & E & EiUA & Fo & Fm & Fv & Fv/Fm \\
\hline Block & 2 & $\mathrm{~ns}$ & $*$ & $\mathrm{~ns}$ & $\mathrm{~ns}$ & $\mathrm{~ns}$ & $\mathrm{~ns}$ \\
Sal & 4 & $*$ & $*$ & $*$ & $\mathrm{~ns}$ & $\mathrm{~ns}$ & $\mathrm{~ns}$ \\
Fertilizer & 3 & $*$ & $\mathrm{~ns}$ & $\mathrm{~ns}$ & $\mathrm{~ns}$ & $\mathrm{~ns}$ & $\mathrm{~ns}$ \\
Sal x Fertilizer & 12 & $*$ & $*$ & $*$ & $\mathrm{~ns}$ & $\mathrm{~ns}$ & $\mathrm{~ns}$ \\
\hline CV & & 17,37 & 21,51 & 7,93 & 9,84 & 11,81 & 2,98 \\
\hline
\end{tabular}

Note. ${ }^{*}=$ significant at 0.05 probability level; $\mathrm{ns}=$ not significant; $\mathrm{SF}=$ Sources of variation; $\mathrm{DF}=$ Degrees of freedom $; \mathrm{Sal}=$ salinity levels; $\mathrm{CV}=$ coefficient of variation . 
A

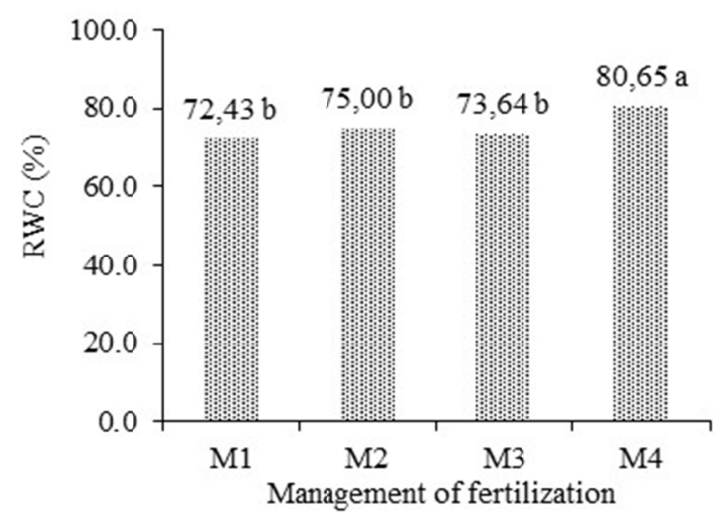

B

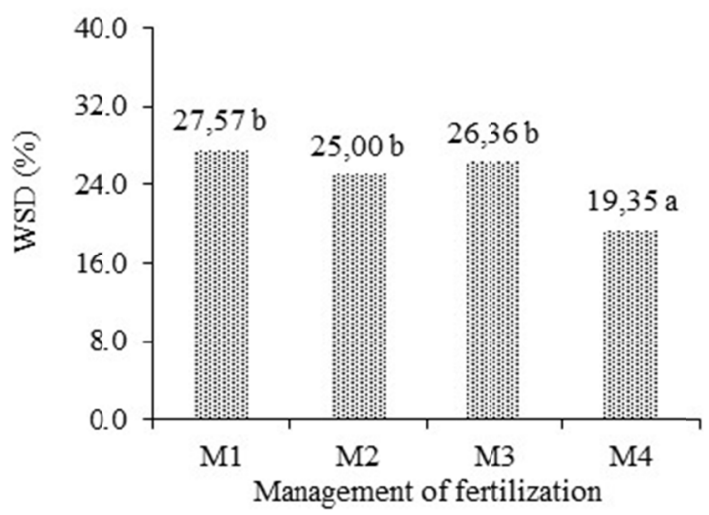

Figure 1. Relative water content in the leaf-RWC (A) and water saturation deficit-WSD (B) of West Indian cherry irrigated with saline water under different management of nitrogen and phosphorus fertilization (M) at 45 days after applying the saline levels

Note. $\mathrm{M} 1=100: 100 \% \mathrm{P} / \mathrm{N} ; \mathrm{M} 2=140: 100 \% \mathrm{P} / \mathrm{N} ; \mathrm{M} 3=100: 140 \% \mathrm{P} / \mathrm{N}$ e M4 $=140: 140 \% \mathrm{P} / \mathrm{N} ;$ Means followed by different letters indicate significant difference between treatments by Tukey test $(\mathrm{p}<0.05)$.

The $\mathrm{CO}_{2}$ assimilation rate $(A)$ of West Indian cherry fertilized with $100: 100 \% \mathrm{P} / \mathrm{N}$ was reduced by the water salinity levels, with decrease of $60.2 \%$ at the highest saline level $\left(\mathrm{ECw}=3.8 \mathrm{dS} \mathrm{m} \mathrm{m}^{-1}\right)$, in relation to the lowest $\mathrm{ECW}$ level tested $\left(0.6 \mathrm{dS} \mathrm{m}^{-1}\right)$ (Figure 2A). The decrease in photosynthesis resulted from the accentuated reduction in stomatal conductance $(g s)$ and, consequently, in transpiration rate $(E)$ and instantaneous water use efficiency (WUEi), denoting that factors of stomatal nature act on the gas exchange activities of West Indian cherry under salt stress conditions (Figures 2D, 2E, and 2F). The stomata, directly involved in the regulation of gas exchange activities, were affected in their activity by salinity, with direct influence on the water loss by the plant, which resulted in water saturation deficit (Figure 1B) in leaf tissues. Stomatal closure acts on the $\mathrm{CO}_{2}$ inflow, thus regulating photosynthesis (Lacerda et al., 2006; Hussain et al., 2012; Suassuna et al., 2014). The stomatal closure of West Indian cherry under salt stress conditions is possibly related to the reduction in the absorption of water and consequently of salts, resulting in attenuation of the toxicity by specific ions (Syvertsen \& Garcia-Sanchez, 2014), but with reduction in the photosynthetic activity of the plant (Figure 2A).

In plants fertilized with $100: 100 \% \mathrm{P} / \mathrm{N}$, there was also an increment in the internal $\mathrm{CO}_{2}$ concentration $(\mathrm{C} i)$ due to the increase in irrigation water salinity and, consequently, a reduction in the instantaneous carboxylation efficiency $(\mathrm{EiCi})$, which was more expressive from ECw $3.0 \mathrm{dS} \mathrm{m}^{-1}$ on (Figures $2 \mathrm{~B}$ and $2 \mathrm{C}$ ). The reductions in $\mathrm{EiCi}$ are related to the decreases in photosynthesis $(A)$ and increase in $\mathrm{Ci}$, as a consequence of the accumulation of carbon in the cells, due to probably low efficiency of the enzyme Ribulose-1,5-bisphosphate carboxylase/oxygenase (RuBisCO) in the carboxylation of $\mathrm{CO}_{2}$, because of the salt stress, indicating that factors of non-stomatal nature act on the photosynthetic activity of the plants, such as low availability of reducing potential (ATP and NADPH) (Machado et al., 2010; Silva et al. 2014; Taiz et al., 2015).

West Indian cherry fertilized with $100: 140 \% \mathrm{P} / \mathrm{N}$ showed a quadratic response, with highest photosynthesis rate $\left(A=3.59 \mu \mathrm{mol} \mathrm{m}^{-2} \mathrm{~s}^{-1}\right)$ at the ECw level of $1.8 \mathrm{dS} \mathrm{m}^{-1}$, decreasing from this value on until the lowest estimated value of $1.87 \mu \mathrm{mol} \mathrm{m}^{-2} \mathrm{~s}^{-1}$ in plants irrigated with the saline level of $3.8 \mathrm{dS} \mathrm{m}^{-1}$ (Figure 2A). Sá et al. (2015), in a study with citrus plants, also observed increment of $A$, which was attributed to the increase in the tolerance of the plants, aiming to enhance the synthesis of sugar, via photosynthesis, in order to minimize the deleterious effects caused by the alteration in the osmotic and ionic homeostasis, besides increasing the sap flow, to accelerate the compartmentation of toxic ions in the vacuole (Volkov \& Amtmann, 2006).

The results observed for photosynthesis (Figure 1A) in plants fertilized with 100:140\% P/N are consistent with those of $\mathrm{C} i$, since the reduction in $\mathrm{C} i$ is related to the $\mathrm{CO}_{2}$ consumption by the RuBisCO enzyme, and to the increase in the instantaneous carboxylation efficiency ( $E i C i)$. As found for $A$, the variables $E$ and $W U E i$ also showed a quadratic behavior due to the treatments. The increment of $40 \%$ in $\mathrm{N}$ dose probably stimulated greater synthesis of amino acids and soluble sugars, which contributed to a better osmotic adjustment (Ashraf \& Harris, 2004), favoring the photosynthetic activity of the plants under salt stress conditions. 
A

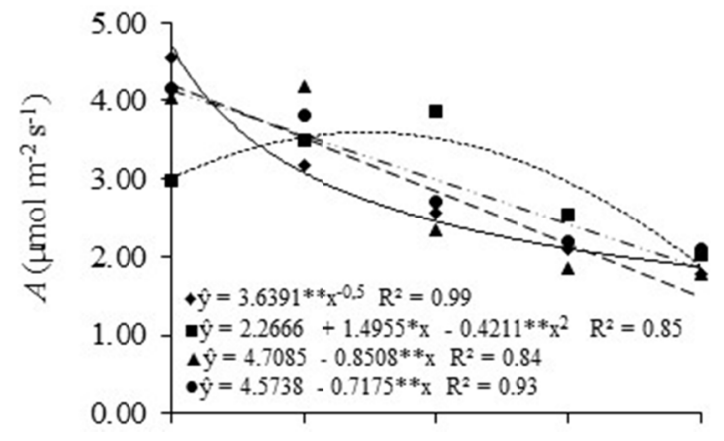

$\mathrm{C}$

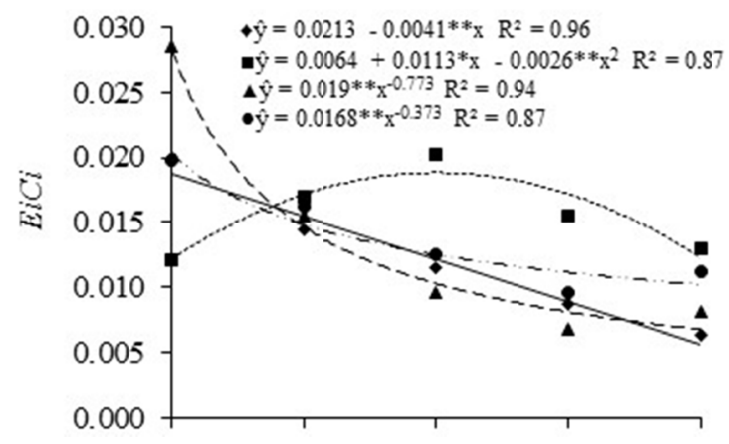

$\mathrm{E}$

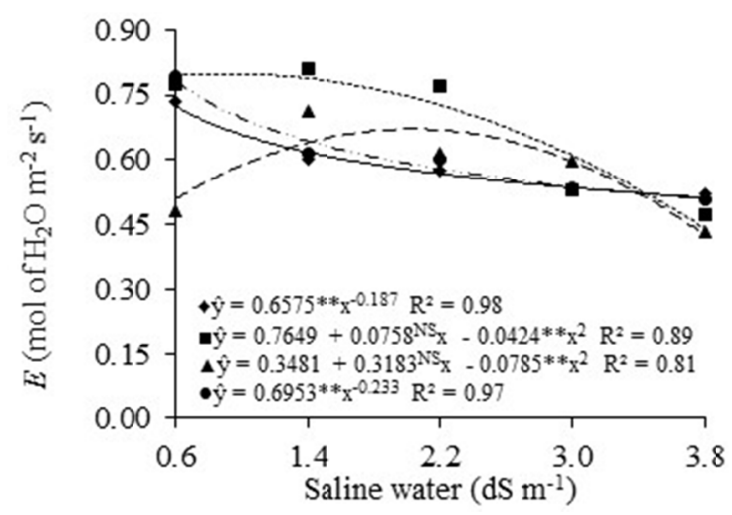

B

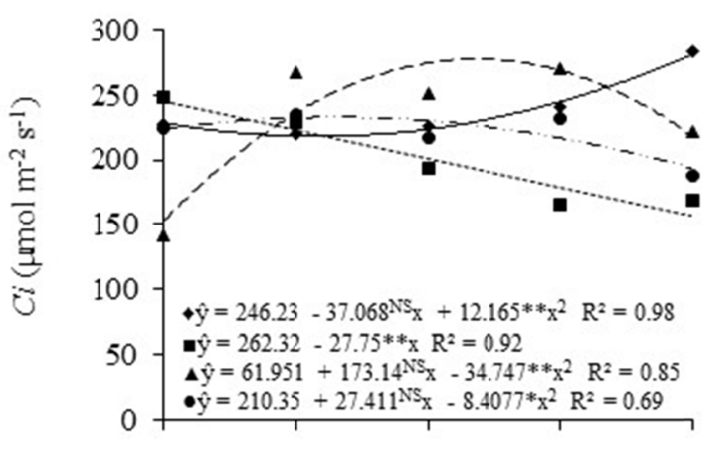

$\mathrm{D}$

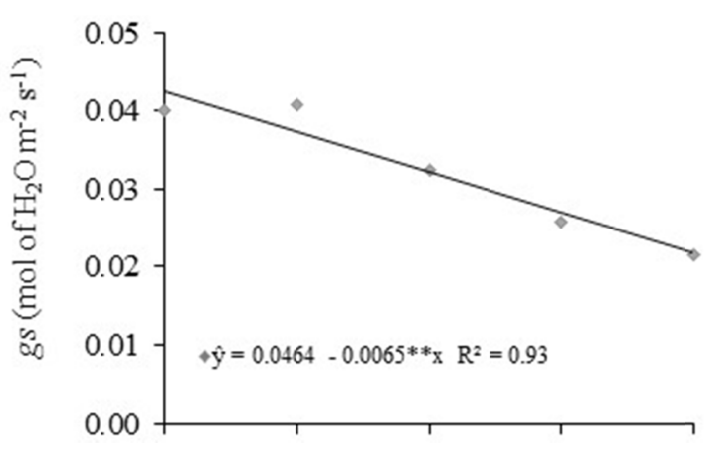

$\mathrm{F}$

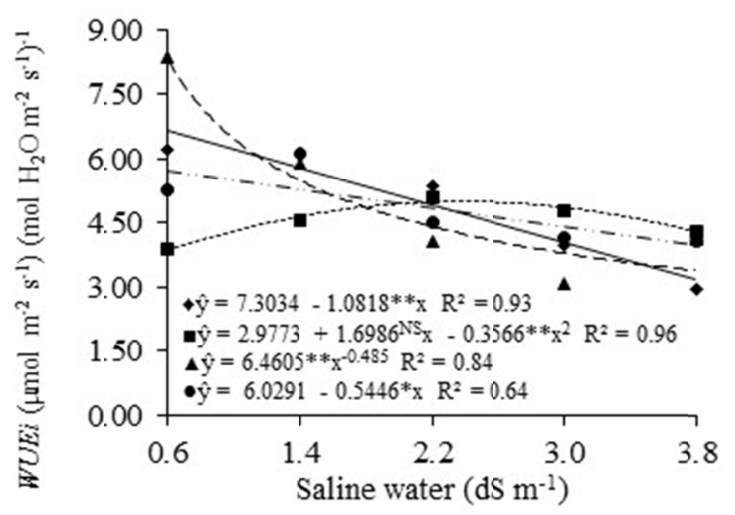

Figure 2. $\mathrm{CO}_{2}$ assimilation rate- $A(\mathrm{~A})$, internal $\mathrm{CO}_{2}$ concentration- $\mathrm{Ci}(\mathrm{B})$, instantaneous carboxylation efficiency-EiCi $(\mathrm{C})$, stomatal conductance-gs $(\mathrm{D})$, transpiration- $E(\mathrm{E})$, and instantaneous water use efficiency-WUEi $(\mathrm{F})$ of West Indian cherry irrigated with saline water under different management of nitrogen and phosphorus fertilization at 45 days after applying the salinity treatments

Note. $\mathrm{M} 1=-100: 100 \% \mathrm{P} / \mathrm{N} ; \mathrm{M} 2=\boldsymbol{\Delta} 140: 100 \% \mathrm{P} / \mathrm{N} ; \mathrm{M} 3=\boldsymbol{-} 100: 140 \% \mathrm{P} / \mathrm{N}$ and $\bullet 140: 140 \% \mathrm{P} / \mathrm{N} ; * *$ and $*=$ significant at 0.01 and 0.05 probability, respectively; $\mathrm{NS}=$ not significant.

The $\mathrm{CO}_{2}$ assimilation rate of plants fertilized with $140: 100 \% \mathrm{P} / \mathrm{N}$ and $140: 140 \% \mathrm{P} / \mathrm{N}$ was significantly reduced by the increment in $\mathrm{ECw}$, with decreases of 0.85 and $0.72 \mu \mathrm{mol} \mathrm{m}^{-2} \mathrm{~s}^{-1}$ per unit increase in water salinity (Figure 2A). In agreement with the reductions of $A$, the internal $\mathrm{CO}_{2}$ concentration $(\mathrm{Ci})$ also increased in West Indian cherry with the increment in water salinity, which resulted in $E i C i$ reductions of 75 and $50 \%$, in the plants subjected to the highest ECw level $\left(3.8 \mathrm{dS} \mathrm{m}^{-1}\right)$ and in comparison to those cultivated using water of $0.6 \mathrm{dS} \mathrm{m}^{-1}$ (Figures $2 \mathrm{~B}$ and $\mathrm{C}$ ). This suggests the action of non-stomatal factors on the photosynthetic activity, such as the 
reduction in the synthesis of ATP and NADPH in the photochemical stage of the photosynthesis (Hussain et al., 2012; Silva et al., 2014). These results are relevant, because there were also reductions in $E$ and WUEi, resulting from the increase in irrigation water salinity (Figures $2 \mathrm{E}$ and $2 \mathrm{~F}$ ). The increment in $\mathrm{Ci}$ may be an evidence for the lack of restriction in $\mathrm{CO}_{2}$ inflow, and stomatal closure may be related to the tolerance mechanisms of the species to salt stress, aiming at the reduction of water loss and, consequently, reduction in the absorption of salts dissolved in the irrigation water, minimizing the effects of toxicity by specific ions (Syvertsen \& Garcia-Sanchez, 2014).

Still regarding Figure 2A, the increase of water salinity triggered reductions in the photosynthetic activity of the West Indian cherry, but the carbon assimilation of those that received increment of $40 \%$ in the recommended dose of $\mathrm{P}$ and/or $\mathrm{N}$ was higher than that observed in plants cultivated with $100: 100 \% \mathrm{P} / \mathrm{N}$ up to the $\mathrm{ECw}$ level of $3.0 \mathrm{dS} \mathrm{m}^{-1}$. Therefore, the increment in $\mathrm{P}$ and/or $\mathrm{N}$ doses had positive influence on the mitigation of the effects caused by water salinity on plants.

For stomatal conductance $(g s)$, there was a negative linear effect, with reduction of 0.0065 ( $m o l$ of $\mathrm{H}_{2} \mathrm{O} \mathrm{m}^{-2} \mathrm{~s}^{-1}$ ) per unit increase in irrigation water salinity (Figure 2D). It can be observed a direct relationship between stomatal movement and other parameters of gas exchanges, because the reductions in $A, C i, E$ and $W U E i$ in the West Indian cherry corresponded to values that indicate stomatal closure. In general, these results corroborate the contents reported in the literature, especially in C3 plants, as the West Indian cherry, since the stomata are directly responsible for the regulation of gas exchanges, so that their closure limits the $\mathrm{CO}_{2}$ inflow and transpiration rate, also affecting the instantaneous water use efficiency (Silva et al., 2014; Sá et al., 2015), as observed in the present study.

Regarding chlorophyll $a$ fluorescence, as already mentioned in the discussion of the data in Figure 3, only the initial fluorescence of the plants was affected by the treatments, with significant effects of interaction between the factors. In the control treatment, in which $\mathrm{P}$ and $\mathrm{N}$ were applied in equal proportion $(100: 100 \% \mathrm{P} / \mathrm{N})$, the initial fluorescence (Fo) had linear effect with the increment in irrigation water salinity, increasing by $10.92 \%$ per unit increase in ECw. The Fo value was $32.82 \%$ higher in the treatment with $3.8 \mathrm{dS} \mathrm{m}^{-1}$, in comparison to the lowest concentration of salts. It may seem a paradox, but such increment is not beneficial to the plants.

According to the literature, $F_{O}$ is an important parameter of fluorescence, because the increase in its value indicates damages in the photosynthetic apparatus, since it is a sign of loss of light energy, because the quinone (primary electron acceptor) is in a state of oxidation in the reaction center (P680), affecting the energy transfer of photosystem II (PSII) (Mendonça et al., 2010; Hussain et al., 2012; Silva et al., 2014). In plants supplemented with $\mathrm{P}$ and/or N $(100: 140 \% \mathrm{P} / \mathrm{N} ; 140: 100 \% \mathrm{P} / \mathrm{N} ; 140: 140 \% \mathrm{P} / \mathrm{N})$, there was no increment in the Fo levels, even with the increase in the concentration of salts in the irrigation water (Figure 3). Therefore, in West Indian cherry the supplementation of $\mathrm{P}$ and/or $\mathrm{N}$ favored the energetic balance of the photosynthetic processes, since it resulted in reduction of initial fluorescence or prevented the increase of this variable at the highest levels of electrical conductivity of irrigation water (Maxwell \& Johnson, 2000).

Despite the observed variation in Fo, the other parameters of fluorescence (Fv, Fm) were not affected by the salinity levels. Based on Maxwell and Johnson (2000), and Baker and Rosenqvst (2004), it is inferred that the West Indian cherry crop has good energetic stability, because the quantum efficiency of photosystem II ( $\mathrm{Fv} / \mathrm{Fm})$ was not affected, even with $3.8 \mathrm{dS} \mathrm{m}^{-1}$ of salinity in the water used to irrigate the plants for 45 days (Table 2). The energetic stability of the plants, when subjected to supplementary fertilization with N (Figure 3), may be related to the mitigating action in situations of stress, due to its functionality in the osmotic adjustment (protective osmolytes) and in the protection of macromolecules against the reaction oxygen species (Esteves \& Suzuki, 2008; Gupta \& Huang, 2014). 


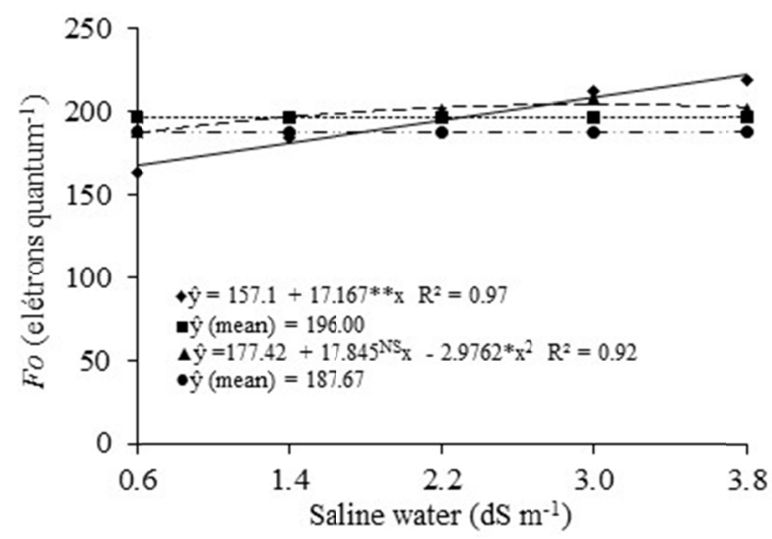

Figure 3. Initial fluorescence (Fo) of West Indian cherry irrigated with saline water under different management of nitrogen and phosphorus fertilization at 45 days after applying the saline levels

Note. $100: 100 \% \mathrm{P} / \mathrm{N} ;-100: 140 \% \mathrm{P} / \mathrm{N} ; \Delta 140: 100 \% \mathrm{P} / \mathrm{N}$ and $\bullet 140: 140 \% \mathrm{P} / \mathrm{N} ; * *$ and $*=$ significant at 0.01 and 0.05 probability, respectively; NS $=$ not significant.

\section{Conclusions}

The joint action of nitrogen and phosphorus, at doses of 140:140\% N/P, increased leaf turgor in West Indian cherry regardless of the saline level of the irrigation water. The increase in salinity reduced stomatal conductance, leading to damages in the photosynthesis of West Indian cherry, except those that received increment of $40 \%$ in the nitrogen dose, which showed increase in photosynthesis up to the saline level of $2.2 \mathrm{dS} \mathrm{m}^{-1}$. The increment of $40 \%$ in the doses of nitrogen and phosphorus reduces the effects of water salinity, for not affecting fluorescence and quantum efficiency of photosystem II.

\section{Reference}

Adriano, E., Leonel, S., \& Evangelista, R. M. (2011). Qualidade de fruto da aceroleira cv. Olivier em dois estádios de maturação. Rev. Bras. de Frut., 33(Special), 541-545. https://doi.org/10.1590/S0100-29452011 000500073

Ashraf, M., \& Harris, P. J. C. (2004). Potential biochemical indicators of salinity tolerance in plants. Plant Sci., 166(1), 3-16. https://doi.org/10.1016/j.plantsci.2003.10.024

Ayers, R. S., \& Westcot, D. W. (1985). Water quality for agriculture (p. 174). Food and Agriculture Organization of the United Nations.

Baker, N. R., \& Rosenqust, E. (2004). Aplication of chlorophyll fluorescence can improve crop production strategies: An examination of future possibilities. J. of Exp. Bot., 55(403), 1607-1621. https://doi.org/ $10.1093 / \mathrm{j} x \mathrm{~b} / \mathrm{erh} 196$

Claessen, M. E. C. (1997). Manual de métodos de análise de solo (2nd ed., p. 212). Rio de Janeiro: Embrapa-CNPS.

Esashika, T., Oliveira, L. A., \& Moreira, F. W. (2013). Resposta da aceroleira a adubação orgânica, química e foliar num Latossolo da Amazônia Central. Rev. de Ciên. Agrá., 36(4), 399-410.

Esteves, B. S., \& Suzuki, M. S. (2008). Efeito da salinidade sobre as plantas. Oecologia Bras., 12(4), 662-679. https://doi.org/10.4257/oeco.2008.1204.06

Ferreira, D. F. (2011). Sisvar: A computer statistical analysis system. Ciên. \& Agrotec., 35(6), 1039-1042. https://doi.org/10.1590/S1413-70542011000600001

Furtado, G. F., Sousa Junior, J. R., Xavier, D. A., Andrade, E. M. G., \& Sousa, J. R. M. (2014). Pigmentos fotossintéticos e produção de feijão Vigna unguiculada L. Walp sob salinidade e adubação nitrogenada. Rev. Ver. de Agro. e Des. Sust., 9(2), 291-299.

Guedes Filho, D. H., Santos, J. B., Gheyi, H.R., Cavalcante, L. F., \& Santos Junior, J. A. (2015). Componentes de produção e rendimento do girassol sob irrigação com águas salinas e adubação nitrogenada. Irriga., 20(3), 514-527. https://doi.org/10.15809/irriga.2015v20n3p514 
Gupta, B., \& Huang, B. (2014). Mechanism of salinity tolerance in plants: Physiological, biochemical, and molecular characterization. Int. J. of Gen., 2014(1), 1-18. https://doi.org/10.1155/2014/701596

Hussain, S., Luro, F., Costantino, G., Ollitrault, P., \& Morillon, R. (2012). Physiological analysis of salt stress behavior of citrus species and genera: Low chloride accumulation as an indicator of salt tolerance. South Afri. J. of Bot., 81(7), 103-112. https://doi.org/10.1016/j.sajb.2012.06.004

Lacerda, C. F., Morais, H. M. M., Prisco, J. T., Enéas Gomes Filho, E., \& Bezerra, M. A. (2006). Interação entre salinidade e fósforo em plantas de sorgo forrageiro. Rev. Ciên. Agron., 37(3), 258-263.

Leonardo, M., Broetto, F., Boas, R. L. V., Marchese, J. A., Tonin, F. B., \& Regina, M. (2008). Estado nutricional e componentes da produção de plantas de pimentão conduzidas em sistema de fertirrigação durante indução de estresse salino em cultivo protegido. Bragantia, 67(4), 883-889. https://doi.org/10.1590/S0006-8705 2008000400010

Lima, G. S., Gheyi, H. R., Nobre, R. G., Soares, L. A. A., Xavier, D. A., \& Santos Junior, J. A. (2015). Water relations and gas exchange in castor bean irrigated with saline water of distinct cationic nature. Afric. J. of Agric. Res., 10(13), 1581-1594. https://doi.org/10.5897/AJAR2015.9606

Machado, D. F. S. P., Machado, E. C., Machado, R. S., \& Ribeiro, R.V. (2010). Efeito da baixa temperatura noturna e do porta-enxerto na variação diurna das trocas gasosas e na atividade fotoquímica de laranjeira 'Valência'. Rev. Bras. de Frut., 32(2), 351-359. https://doi.org/10.1590/S0100-29452010005000064

Maxwell, K., \& Johnson, G. N. (2000). Chlorophyll fluorescence: a pratical guide. J. of Exp. Bot., 51(3), 659-668. https://doi.org/10.1093/jexbot/51.345.659

Medeiros, J. F. De, Lisboa, R. A., Oliveira, M., Silva Júnior, M. J., \& Alves, L. P. (2003). Caracterização das águas subterrâneas usadas para irrigação na área produtora de melão da Chapada do Apodi. Rev. Bras. de Eng. Agrí. Ambiental., 7(3), 469-472. https://doi.org/10.1590/S1415-43662003000300010

Munns, R., \& Tester, M. (2008). Mechanism of salinity tolerance. Ann. Rev. of Plant Biol., 59(3), 651-681. https://doi.org/10.1146/annurev.arplant.59.032607.092911

Musser, R. S. (1995). Tratos culturais na cultura da acerola. In A. R. São José, \& R. E. Alves (Eds.), Acerola no Brasil: Produção e mercado (pp. 47-52). Vitória da Conquista: DFZ/UESB.

Oliveira, F. R. A., Oliveira, F. A. O., Medeiros, J. F., Sousa, V. F. L., \& Freire, A. G. (2010). Interação entre salinidade e fósforo na cultura do rabanete. Rev. Ciên. Agron., 41(3), 519-526. https://doi.org/10.1590/ S1806-66902010000400003

Sá, F. V. S., Brito, M. E. B., Silva, L. A., Moreira, R. C. L., Fernandes, P. D., \& Figueiredo, L. C. (2015). Fisiologia da percepção do estresse salino em híbridos de tangerineira-Sunki Comum sob solução hidropônica salinizada. Comunicata Scient., 6(4), 463-470. https://doi.org/10.14295/cs.v6i4.1121

Santana, M. J., Carvalho, J. A., Silva, E. L., \& Miguel, D. S. (2011). Efeito da irrigação com água salina em um solo cultivado com o feijoeiro (Phaseolus vulgaris L.). Ciên. \& Agrotec., 27(2), 443-450. https://doi.org/ 10.1590/S1413-70542003000200027

Santos, R. V., Cavalcante, L. F., \& Vital, A. F. M. (2010). Interações salinidade fertilidade do solo. In H. R. Gheyi, C. F. Lacerda, \& N. S. Dias (Eds.), Manejo da salinidade na agricultura: Estudos básicos e aplicados (pp. 221-250). Fortaleza: INCT Sal.

Silva, L. A. S., Brito, M. E. B., Sá, F. V. S., Moreira, R. C. L. M., Soares Filho, W. S., \& Fernandes, P. D. (2014). Mecanismos fisiológicos em híbridos de citros sob estresse salino em cultivo hidropônico. Rev. Bras. de Eng. Agrí. Ambiental., 18(Special), S1-S7. https://doi.org/10.1590/1807-1929/agriambi.v18nsupps1-s7

Suassuna, J. F., Fernandes, P. D., Brito, K. S. A., Nascimento, R., Melo, A. S., \& Brito, M. E. B. (2014). Trocas gasosas e componentes de crescimento em porta-enxertos de citros submetidos à restrição hídrica. Irriga., 19(3), 464-477. https://doi.org/10.15809/irriga.2014v19n3p464

Syvertsen, J. P., \& Garcia-Sanchez, F. (2014). Multiple abiotic stresses occurring with salinity stress in citrus. Env. and Exp. Botany, 103(1), 128-137. https://doi.org/10.1016/j.envexpbot.2013.09.015

Taiz, L., Zeiger, E., Møller, I. M., \& Murphy, A. (2015). Plant physiology and development (6th ed., p. 761). New York: Sinauer Associates. 
Volkov, V., \& Amtmann, A. (2006). Thellungiella halophila, a salt-tolerant relative of Arabidopsis thaliana, has specific root ion-channel features supporting $\mathrm{K}^{+} / \mathrm{Na}^{+}$homeostasis under salinity stress. The Plant Journal, 48(3), 342-353. https://doi.org/10.1111/j.1365-313X.2006.02876.x

\section{Copyrights}

Copyright for this article is retained by the author(s), with first publication rights granted to the journal.

This is an open-access article distributed under the terms and conditions of the Creative Commons Attribution license (http://creativecommons.org/licenses/by/4.0/). 